ELORE (ISSN 1456-3010), vol. 15 - 2/2008.

Julkaisija: Suomen Kansantietouden Tutkijain Seura ry.

[http://www.elore.fi/arkisto/2_08/jar2_08.pdf]

\title{
KiRJA-ARVIO:
}

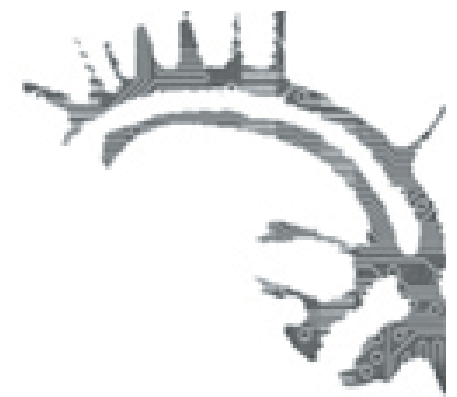

\section{KOULUETNOGRAFIAN KIINNOSTAVILLA JÄLJILLÄ}

Lappalainen, Sirpa \& Hynninen, Pirkko \& Kankkunen, Tarja \& Lahelma, Elina

\& Tolonen, Tarja (toim.) 2007: Etnografia metodologiana - lähtökohtana koulutuksen tutkimus. Tampere: Vastapaino. 283 sivua.

\section{Helmi Järviluoma-Mäkelä}

Pitkän linjan suomalaiset kouluetnografian tekijät ovat toimittaneet kelpo kirjan, jossa he avaavat etnografisia tutkimusprosessejaan. Kaikki kirjoittajat ovat mukana jo 1980-luvun loppupuolelta saakka toimineessa Koulutus ja sukupuoli -tutkimusverkostossa. Useimmat heistä ovat työskennelleet samoissa feministisen kouluetnografian tutkimusprojekteissa.

Kirjan takakannessa mainitaan, että se on suunnattu sekä yliopistojen että ammattikorkeakoulujen erinäisten opinalojen etnografiasta kiinnostuneille tutkijoille ja opiskelijoille. Ilman muuta kirja palvelee oppikirjana. Osin se on oivallinen opas vasta-alkajalle, joka lapsenkengissään ottaa ensimmäisiä askeleitaan etnografian koulupolulla - etenkin silloin, kun tutkijat kuvaavat henkilökohtaisia koettelemuksiaan, ilojaan ja oivalluksiaan. Toisin paikoin sitten ekaluokkalainen tippuu koulubussin kyydistä pysäkille.

\section{KOULUETNOGRAFIAN PERUSTEET}

Elina Lahelma ja Tuula Gordon tunnustavat heti artikkelin Taustoja, lähtökobtia ja avanksia kouluetnografiaan alussa (s. 17), että heidän kuvauksensa kouluetnografian vaiheista on vain yksi mahdollisista tarinoista. Artikkelista saa tiivistetysti ja selkeästi kuvan sekä kansainvälisestä että suomalaisesta kouluetnografiasta. Ehkä vielä hyödyllisempi kirjoituksesta olisi tullut, jos muutamat kirjoittajien hankeraporttia muistuttavat osiot olisi kirjoitettu tyylikkäämmin. 


\section{KOULUETNOGRAFIAN KIINNOSTAVILLA JÄJILÄ}

Artikkeli Koulun arkea tutkimassa (Tuula Gordon, Pirkko Hynninen, Elina Lahelma, Tuija Metso, Tarja Palmu ja Tarja Tolonen) on nimenomaan mainio vastaalkajan opas. Kollektiivisen etnografian verhoa raotetaan kiinnostavasti. Kirjoittajat analysoivat projektinsa Kansalaisuus, erot ja marginaalisuus koulussa - lähtökobtana sukupuoli perusasetelmia, valmistautumista kenttätyöhön ja kentällä työskentelyä. Kirjoituksesta saa eväitä myös kokeneempi tutkija, sillä hanke vaikuttaa ihailtavan järjestelmälliseltä. Mallia voi ottaa vaikkapa tarkastelutasojen rajaamisesta (s. 43): projektilaiset käyttivät sekä koulun tasojen että omien kokemusten analysointiin jaottelua viralliseen, informaaliin ja fyysiseen tasoon. Sen sijaan en tiedä, kannattaako ottaa mallia siitä valtavasta materiaalimäärästä, joka kerättiin. Artikkeli on innoittuneesti kirjoitettu. Tutkijan alitajunnan viestitkin otetaan vakavasti. Tässä on mukavasti, eikä kuitenkaan päälleliimatusti kuvattu se, että kenttätyövaiheen aikana nähdyt unet ovat "paljastavia". Hankkeen fun-metodologiasta aion ainakin välittömästi ottaa oppia. Kokoukset pidetään tiloissa, joissa tutkijan ruumis viihtyy!

\section{EETTISIÄ POHDINTOJA}

Kirjan useissa artikkeleissa on eettisiä pohdintoja, jotka ovat lukijalle kuin lukijalle ehdottoman hyödyllisiä. Kuten Sirpa Lappalainen toteaa artikkelissaan Rajamaalla - etnografinen tarina kenttätyöstä lasten parissa, feministisessä etnografiassa eettisten ongelmien pohtiminen on jatkuvaa, sillä tutkimus on riippuvaista ihmisten älyllisistä suhteista ja sitoutumisesta. Hän kuvaa mielenkiintoista eettistä ristiriitaa, joka syntyi, kun Lappalainen, varhaiskasvatusta tutkiva etnografi, halusi irrottautua kasvatuksellisesta auktoriteetista tutkimustilanteessa. Opettaja halusi mieluusti kategorisoida tutkijan yhdeksi "aikuisista" lapsiryhmän keskellä; reuna-alueilla pysyttelevä tutkija taas etsi keinoja tämän kategorian kiertämiseen sanoin ja teoin. Lappalainen kommentoi toisessa artikkelissaan Havainnoinnista kirjoitukseksi myös ajankohtaista kysymystä tutkimusaineistojen arkistoinnista (s. 132-137). Mitä ventovieras tutkija, jonka ruumiin lävitse havainnot eivät ole kulkeneet, saa irti etnografin aineistoista? Mitä eettisiä ongelmia tässä voi ilmetä?

Myös Tarja Kankkusen Monimediaisuuden äärellä nostaa esiin yksioikoisten eettisten ratkaisujen ongelmat. Kouluetnografiassa käytännöksi on muodostunut, että videoissa esiintyvien tutkittavien kasvot tehdään teknisin keinoin jälkikäteen tunnistamattomiksi. Eettisistä syistä tehty naamiointi - Kankkusen tapauksessa hauskoin naamioin - kääntyy eettisesti ongelmalliseksi. Kuten Kankkusen siteeraama Amanda Coffey on todennut, itse asiassa multimediasta luodaan tällöin vain aikuisille tarkoitettu tila silloin kun lasten äänet, ruumiit, kasvot, identiteetit, kokemukset ja osallistuminen jätetään pois. Monimediaisuusartikkeli kuuluu kirjan mielenkiintoisimpien joukkoon. Kuvaa tai ääntä multimediaa varten työstettäessä aineistoa on pakko lähestyä äärimmäisen tarkasti. Tällä on positiivinen vaikutus analyysiin. 
HeLmi JärVILUOMA

\section{ETNOGRAFISIA KERUUPROSESSEJA}

Hyvinä oppikirja-artikkeleina nostan esiin myös haastattelua käsittelevät artikkelit. Tarja Tolosen ja Tarja Palmun Etnografia, haastattelu ja (valta)positiot on jäsentynyt, hyvin kirjoitettu ja siksi sujuvaa luettavaa. Samaten Reetta Mietolalla Etnografisesta haastattelusta etnografiseen analyysiin on tarkka ote etnometodologisväritteiseen haastattelun analyysiin. Tiivistäminen ei tosin olisi tehnyt jälkimmäiselle kirjoitukselle pahaa.

Etnografinen tutkimusprosessi ei solju siististi aineiston keruusta analyysin kautta kirjoittamiseen. Miksiköhän alan kirjoissa kuitenkin artikkelit useimmiten sijoitetaan tähän järjestykseen? Nytkin kirja lopetetaan Katariina Hakalan ja Pirkko Hynnisen Etnografisesta tietämisestä-artikkeliin ja Ulla-Maija Salon kirjoitukseen Etnografinen kirjoittaminen. Liekö syynä myös se, että artikkelit ovat astetta edeltäviä kirjoituksia teoreettisempia. Yläkoululaisille hyvin hyödyllistä luettavaa siis.

Kirja pysyy melko tarkasti kouluetnografian ja tietyin tavoin rajatun feministisen etnografian sisällä. Rajaus tuo yhtäältä miellyttävää koherenssia. Toisaalta tekijät puhuvat monitieteisyydestä, mutta heidän tutkansa ei osu kovin laajaan osaan suomalaista antropologista tai kulttuurintutkimuksellista etnografiaa. Välillä kouluetnografian erityispiirteet piiloutuvat itsestäänselvyyksiksi. Yksi esimerkki: kirjan kouluetnografit kirjoittavat todella paljon muistiinpanoja paikan päällä, luokissa, koska siellä on luontevaa kirjoittaa. Harvempi tuntemani muu etnografi edes pitää kynää ja paperia esillä havainnointitilanteissa. Kaikki kirjoitetaan jälkikäteen. Tällöin korostuu entisestään kaiken tiedon suodattuminen havainnoitsijan "järjestelmän" lävitse.

Suurin osa artikkeleista on luettavuudeltaan ja kieliasultaan moitteettomia. Kirjaan on kuitenkin jäänyt joitakin toimituksellisia epätasaisuuksia: muutama anglismi, kielivirhe ja vuolassanaisuutta, puutunutta kuin etnografin käsi, kun hän öisin kirjoitti kenttämuistiinpanojaan puhtaaksi. Nämä pikkuseikat eivät kuitenkaan aiheuta millään muotoa sitä, etteikö kirjaan tutustumista voisi suositella kaikille etnografeille.

Helmi Järviluoma-Mäkelä on etnografi ja Joensuun yliopiston kulttuurintutkimuksen professori. 